\title{
PERKEMBANGAN MENTAL BAYI DAN ANAK INDONESIA: HASIL SEANUTS INDONESIA
}

\author{
Basuki Budiman ${ }^{1,3}$, Nurmeida S. Syarief. ${ }^{3}$, Moesijanti Y.E. Soekatri ${ }^{2,3}$ \\ ${ }^{1}$ Pusat Teknologi Terapan Kesehatan dan Epidemiologi Klinik \\ 2Jurusan Gizi, Politeknik Kesehatan Kemenkes Jakarta II \\ 3Persatuan Ahli Gizi Indonesia (PERSAGI) \\ basukibudiman@yahoo.com
}

\begin{abstract}
ABSTRAK
Status gizi ibu hamil mempunyai dampak perkembangan neuropsikologik pada bayi yang dilahirkan. Penyimpangan perkembangan (fisik dan mental) dapat diidentifikasi pada awal kehidupan. South East Asian Nutrition Survey (SEANUTS) adalah penelitian gizi klinik multi-center di empat negara pada bayi dan anak (0,5-12,9 tahun). Negara yang berpartisipasi adalah Indonesia, Malaysia, Thailand dan Vietnam. Data psikologi untuk mengetahui perkembangan mental anak, termasuk aspek yang dikumpulkan. Pengukuran perkembangan anak menggunakan metode Denver Development Screening Test (DDST). Desain penelitian telah dijelaskan oleh Sandjaja, dkk. dalam artikel yang dimuat pada jurnal ini. Hasil penelitian menunjukkan bahwa anak Indonesia berusia balita yang dideteksi mengalami penyimpangan perkembangan (all four) sebesar 21,6 persen. Secara rinci penyimpangan perkembangan motorik kasar sebesar 11,5 persen; kemandirian (personal-social), adaptif-motor halus dan bahasa masing-masing 14,5; 11,8; dan 15,8 persen. Proporsi penyimpangan perkembangan pada bayi (0,5-0,9 tahun) terdeteksi paling besar $(45,8 \%)$ dan secara keseluruhan penyimpangan yang terjadi pada keterampilan berbahasa (bicara) dan perkembangan kemandirian. Secara agregat (pool), hubungan antara penyimpangan neuropsikologik (all four) dan postur tubuh tidak ditemukan. Namun demikian, pada kelompok umur 1,0-2,9 tahun, hubungan tersebut ditemukan, sebaliknya hubungan ini tidak ditemukan pada kelompok umur lain. Pola asuh yang tidak optimal (bahasa, kemandirian) merupakan faktor risiko penyimpangan negatif perkembangan anak.
\end{abstract}

Kata kunci: perkembangan mental, DDST, postur, multi-center

ABSTRACT

\section{MENTAL DEVELOPMENT OF INDONESIAN INFANTS AND CHILDREN: RESULTS OF SEANUTS INDONESIA}

Maternal nutrition during gestation has consequences on mental development of the offspring. The physical and mental disorders can be identified in early life. South East Asian Nutrition Survey (SEANUTS) is a multicenter nutrition study on children aged 0.5 to 12.9 years in which measurement of mental development is also included. The aim of this paper was to describe mental development of Indonesian children 0.5-5.9 years old. Denver Development Screening Test (DDST) was used to identify the deviation of development. Child's height was measured to reflect posture. Detailed study design was described by Sandjaja, et al earlier in this issue. The results revealed that total suspected of late all four development was 21.6 percent, including 11.5, 14.5, 11.8, and 15.8 percent for gross-motor development, personal social, adaptation-fine motor, and language skill, respectively. Infants were the most often detected as severe suspected of late developments $(45.8 \%)$, especially for language and personal social skill. Unadjusted data revealed that there were no associations found between neuropsychological deviation (all four) and posture. When it was adjusted, a significant difference was found only in 1.0-2.9 years old group. We concluded that parenting stimulation as be shown in language skill and personal-social were important risk factors.

Keyword: mental development, DDST, posture, multi-center study

\section{PENDAHULUAN}

$\mathrm{P}$ erkembangan adalah cerminan kematangan fungsi organ tubuh termasuk fungsi neuropsikologik. Kematangan fungsi dipengaruhi oleh berbagai faktor sejak di dalam kandungan. Faktor risiko gangguan kematangan fungsi antara lain kecukupan asupan zat gizi, keamanan pertolongan persalinan, kejadian infeksi intrapartum. Defisiensi iodium maternal pra kehamilan dan selama kehamilan berpengaruh terhadap perkembangan neuropsikologik bayi yang dilahirkan. ${ }^{1-3}$ Anemia, hiperbilirubinemia, asfiksia dan infeksi intrapartum mengganggu 
kematangan perkembangan; demikian pula lahir prematur dan berat badan lahir rendah mengindikasikan ketidak matangan organ tubuh.

Belum matangnya fungsi organ bukan berarti bayi mengalami defek selamanya. Perkembangan yang tertunda masih dapat diperbaiki karena otak, terutama pada awal kehidupan, mempunyai kelenturan memperbaiki sistem fungsi. ${ }^{4,5}$ Oleh karena itu, deteksi perkembangan sedini mungkin menjadi sangat penting. Pertumbuhan dan perkembangan kehidupan sangat cepat pada bayi dan masa anak-anak (1-12 tahun). Alat untuk menapis penyimpangan perkembangan dengan cepat pada anak berusia di bawah enam tahun (banemta) antara lain DENVER II.

Zat gizi makro dan zat gizi mikro berpengaruh secara langsung dan tidak langsung pada perkembangan neuropsikologik termasuk keterampilan gerak otot (motor) anak. Zat gizi makro yang dikaitkan dengan gangguan perkembangan fungsi otak termasuk defisiensi energi protein telah dipublikasi oleh banyak penulis ${ }^{6-10}$, demikian pula zat gizi mikro terutama zat gizi lodium (I), Besi (Fe), Zinc (Zn) dan Vitamin A. ${ }^{11-23}$ Ternyata zat gizi lain baik makro maupun mikro berpengaruh terhadap metabolisme iodium. Anak sekolah di daerah endemik defisiensi iodium yang tampaknya normal, setelah diintervensi dengan iodium, membaik dalam hal memproses informasi, gerak motorik halus, dan masalah penglihatannya. ${ }^{24}$

Secara tidak langsung zat gizi mikro berpengaruh terhadap pertumbuhan melalui gangguan nafsu makan (anorexia), fungsi imunitas, dan risiko sakit (morbidity). Defisiensi energi-protein menghambat metabolisme iodium melalui pengaruh defisiensi energiprotein pada sistem endokrin yaitu terhadap berat kelenjar, struktur histologi, dan fungsi kelenjar tiroid walaupun dalam jangka waktu yang cukup lama. ${ }^{25}$ Di Sudan, Gangguan Akibat Kekurangan lodium (GAKI) dilaporkan berkaitan dengan defisiensi protein-energi, defisiensi vitamin A (KVA) dan Anemia Zat Besi (AZB). ${ }^{26}$

Status Fe berdampak buruk pada tampilan kognitif, perkembangan otak, kinerja fisik dan pada kehamilan serta bayi yang dilahirkan. ${ }^{27,} 28$ Fe berperan pada proses myelinasi saraf. ${ }^{29}$ Meta-analisis 26 penelitian intervensi tentang suplementasi $\mathrm{Fe}$ untuk pencegahan pada anak berusia di bawah lima tahun (balita) dengan desain 'randomized control trial' (RCT) mengungkap peningkatan kognitif dan perkembangan motorik anak yang menderita anemia dan defisiensi Fe. ${ }^{30}$ Pada suatu penelitian yang dirancang secara randomized control trial pada wanita usia subur (WUS, 1835 tahun), disimpulkan bahwa status zat besi merupakan faktor penting yang berpengaruh terhadap kinerja kognitif. Anemia zat besi (AZB) yang berat berpengaruh terutama pada kecepatan proses; sedang Defisiensi Zat Besi (DZB) berpengaruh pada fungsi kognitif. Disimpulkan juga bahwa pengaruh DZB tidak terbatas pada perkembangan otak saja. ${ }^{23}$

Risiko morbiditas, mortalitas dan melahirkan bayi dengan berat badan rendah (BBLR) pada ibu hamil penderita AZB meningkat. AZB berkaitan dengan mortalitas hanya jika AZB berat tetapi tidak pada AZB yang ringan dan sedang. Menurut Hess (2003) hubungan AZB dengan BBLR dan lahir terlalu cepat (tidak cukup bulan) belum dapat disimpulkan karena tidak cukup data. ${ }^{18}$ Demikian pula hubungan AZB dengan kematian neonatal dan perinatal. $A Z B$ yang berat dipercaya tidak hanya DZB saja, defisiensi mikronutrien lain juga terjadi. Jika AZB terjadi pada anak usia 12-18 bulan akan menghambat pertumbuhan yang tidak dapat diperbaiki (irreversible) ${ }^{27}$ dan jika AZB disertai defisiensi iodium pada janin dan awal kehidupan, keduanya dapat menyebabkan retardasi mental dan motor. 31,32

Di Maroko, suplementasi Vitamin A dilaporkan meningkatkan efikasi iodium ${ }^{17}$, namun mekanismenya belum diketahui dengan jelas. Selenium merupakan bagian tak terpisahkan pada enzim glutation-peroksidase (GSH-Px) yang berpengaruh pada deiodinasi T4 menjadi T3.33,34 Konsentrasi Zinc,Kuprum $(\mathrm{Cu})$, Mangan (Mn), Selenium dalam plasma, eritrosit dan urin berubah-ubah menurut status tiroid. ${ }^{34}$

Asfiksia adalah keadaan kegagalan atau gangguan proses pernafasan yang mengakibatkan pasokan oksigen dalam otak tidak mencukupi. Pada gilirannya terjadi kematian sel-sel saraf dan manifestasinya secara klinis terjadi gangguan neuropsikologik. Asfiksia perinatal, asfiksia neonatal atau asfiksia saat lahir adalah kekurangan (deprivation) oksigen yang cukup lama pada proses kelahiran 
bayi. Asfiksia dapat menyebabkan kecacatan fisik. Organ tubuh bayi yang cacat akibat kekurangan pasokan oksigen adalah jantung, paru, hati, ginjal, saluran pencernaan dan terutama otak. Manifestasi asfiksia neonatus adalah cacat mental dan fisik. Cacat mental meliputi ketertundaan perkembangan mental, berkurangnya kemampuan intelektual, dan cacat fisik termasuk kekakuan otot (spastisitas).

Kecacatan yang terjadi dalam kandungan, saat proses kelahiran dan usia di bawah satu tahun jika tidak diintervensi dengan tepat akan terbawa pada umur selanjutnya. Kecacatan tersebut secara cepat dapat dideteksi dengan cara sederhana. Namun kepastian kecacatan harus dideteksi lebih teliti dengan alat lebih canggih dan keahlian lebih mumpuni. Salah satu alat deteksi penyimpangan perkembangan yang sederhana adalah pemeriksaan psikologik metode Denver Development Screening Test (DDST), selanjutnya ditulis DENVER. ${ }^{36,37}$

DENVER, merupakan salah satu alat penapisan perkembangan yang digunakan psikolog/ tenaga kesehatan dalam menapis (screen) penyimpangan perkembangan mental anak berusia di bawah enam tahun (banemta) seawal mungkin. Perkembangan yang menyimpang hasil indentifikasi dan atau yang disimpulkan dari hasil pemeriksaan bukan berarti keterlambatan. Untuk menentukan bahwa penyimpangan tersebut adalah perkembangan yang terlambat, pemeriksaan psikologik lebih lanjut masih perlu dilakukan. Empat aspek yang dicakup dalam Denver II adalah (1) motorik kasar, (2) kemampuan bahasa, (3) adaptif-motorik halus, dan (4) Personal Sosial.

Motorik kasar adalah gerakan umum otot besar, termasuk gerak seimbang, mengangkat kepala sampai terangkat 90 derajat, mengangkat dada dengan bertumpu pada lengan, berjalan mundur, berdiri satu kaki, berlari. Kemampuan Bahasa adalah kemampuan mendengar, mengerti dan menggunakan bahasa. Misalnya, bereaksi terhadap suara, berteriak, menoleh ke arah sumber suara, menggunakan rangkaian tiga kata yang bermakna, menyebut warna, paham dengan dua kata yang berlawanan. Adaptifmotorik halus adalah keterampilan menggunakan otot halus. Contoh, kordinasi mata-tangan, mengikuti gerak benda, memegang dengan telunjuk dan ibu jari, menggambar orang, menggunakan benda kecil. Personal social adalah penyesuaian diri dengan masyarakat dan perhatian terhadap kebutuhan perorangan. Misalnya, menatap wajah, membalas senyum, melambaikan tangan, minum dari cangkir, memakai dan melepas pakaian, gosok gigi tanpa bantuan.

Tulisan ini merupakan potret keadaan perkembangan bayi dan anak Indonesia berusia di bawah enam tahun yang diidentifikasi menyimpang dari norma perkembangan menurut psikologik. Potret ini diperoleh dari hasil penelitian gizi multisenter di empat Negara Asia Tenggara (SEANUTS).

\section{METODE PENELITIAN}

Partisipan adalah anak berusia 0,5-12,9 tahun pada studi gizi_klinik multisenter empat negara ASEAN (SEANUTS).Keempat negara terdiri dari Indonesia, Malaysia, Thailand dan Vietnam). Penelitian di Indonesia dilaksanakan dengan desain adalah potong lintang (cross sectional). Pengambilan sampel berbasis populasi nasional (seluruh Indonesia) anak berusia 0,5-12,9 tahun yang distratifikasi menurut proporsi populasi (PPS) kelompok umur, jenis kelamin dan lokasi (desa dan kota). Alokasi partisipan Indonesia sebanyak 7211 anak yang mencakup 48 kabupaten dari 33 provinsi. Rancangan pemilihan sampel dijelaskan secara lengkap oleh Sandjaja dalam artikel di terbitan ini. ${ }^{37}$ Penapisan perkembangan dilakukan pada setengah jumlah partisipan, yaitu 3600 anak. Pemeriksaan psikologik menggunakan formulir tes (battery) perkembangan anak yaitu DENVER II untuk anak berusia 0,5-5,9 tahun.

Tes DENVER II terdiri dari lembar yang berisi tahapan perkembangan anak. DENVER II pemeriksaan psikologik yang mencakup empat aspek motorik kasar, kemampuan bahasa, adaptif-motorik halus, dan personal sosial. Pemeriksaan psikologik dilaksanakan di ruang khusus yang relatif tenang. Anak berusia banemta diberi mainan sambil diamati perkembangannya. Hasil pengamatan dicatat dalam lembar tingkat pertumbuhan. Lembar tersebut sudah memuat keempat aspek perkembangan. Garis horisontal umur dapat ditemui pada bagian atas dan bagian bawah. Jika kedua garis horizontal dihubungkan membentuk garis vertikal perkembangan 
normal. Anak boleh didampingi namun pengasuh tidak diperkenankan memandu atau membantu anak memecahkan masalah yang diujikan.

Setiap aspek perkembangan diberi skor dalam empat kategori yaitu advance (lebih cepat berkembang) skor 1 , normal $=2$, caution (perlu perhatian) $=3$ dan suspect (dicurigai terlambat) $=4$. Selanjutnya diskor kembali menjadi dua kelompok normal (kategori advance dan normal) dengan skor $=1$ dan kelompok terduga (caution dan suspect) dengan skor 2. Hasil disajikan dalam tabel distribusi menurut postur tubuh anak (status gizi dengan indeks skor $Z$ tinggi badan menurut umur). Baku yang digunakan adalah antropometri $\mathrm{WHO}$ 2005.

\section{HASIL}

Jumlah anak berusia 0,5-5,9 tahun yang sukarela mengikuti pemeriksaan DENVER II secara lengkap sebanyak 1681 anak. Hasil penapisan pemeriksaan psikologi pada anak berusia 0,5-5,9 tahun dengan metode DDST menunjukkan proporsi anak yang terduga mengalami penyimpangan perkembangan mental sebesar 19,4 persen. Secara menyeluruh (all four), proporsi penyimpangan perkembangan mental tampak terdeteksi besar pada kelompok 0,5-0,9 tahun (45,3\%). Pada kelompok yang lebih tua sekitar sebesar 17,3 dan 18,6 persen (Grafik 1). Distribusi proporsi ini sangat berbeda dalam kelompok umur (ChiSquare $=58,321 ; \mathrm{df} 2 ; \mathrm{p}=0,000$ ).

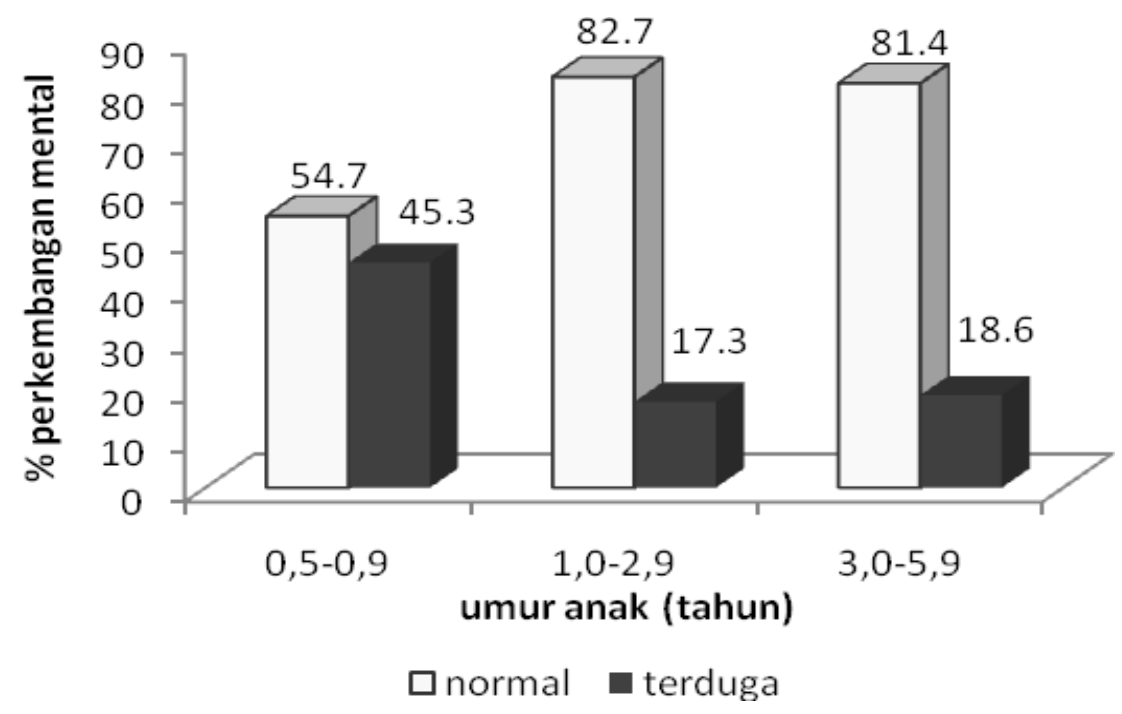

Grafik 1

Proporsi Penyimpangan Perkembangan Mental Anak Usia 0,5-5,9 Tahun menurut Kelompok Umur

Tabel 1

Proporsi Perkembangan Mental menurut Postur Tubuh

\begin{tabular}{lrrrr}
\hline \multirow{2}{*}{ Perkembangan Mental } & \multicolumn{2}{c}{ Postur Tubuh* $(\%)$} & \multicolumn{2}{c}{ Total } \\
& Sangat pendek & Pendek & Normal & \\
\hline Normal & 73,1 & 79,2 & 78,8 & 78,4 \\
Terduga & 26,9 & 20,8 & 21,2 & 21,6 \\
Total & 100,0 & 100,0 & 100,0 & 100,0 \\
\hline
\end{tabular}

*HAZ menurut kategori WHO 
Pada berbagai keadaan postur tubuh, proporsi terduga terlambat secara menyeluruh (all four) pada anak pendek dan sangat pendek $(35,8 \%)$ tidak terpaut jauh dibandingkan anak yang posturnya normal $(34,2 \%)$ (Tabel 1). Secara statistik, perkembangan postur tubuh pada anak berusia 0,5-5,9 tahun yang mengalami retardasi tidak ditemukan asosiasi dengan penyimpangan perkembangan mental secara menyeluruh (Chi-Square $=1,945 ; d f$; $p=0,378$ ).

Proporsi penyimpangan perkembangan mental berbagai aspek pada anak dengan postur gabungan pendek dan sangat pendek, sedikit lebih besar dari anak dengan postur normal. Namun perbedaan ini bersifat kebetulan.

Proporsi penyimpangan dalam hal keterampilan bahasa (SLS) dan gerak (SMD) lebih besar dibandingkan keterampilan adaptasi (SAS) dan personal sosial (SPS) (Tabel 2). Namun demikian, tidak ditemukan asosiasi antar anak menurut postur. Proporsi keempat aspek perkembangan mental (SLS, SAS, SPS dan SMD) pada anak dengan postur normal sangat kecil $(<15 \%)$.

Pada Tabel 3 disajikan perkembangan mental dan postur tubuh. Jika dicermati besar proporsi pada kelompok umur 0,5-0,9 dan 1,02,9 tahun tampak gradasi semakin kecil, namun gradasi tidak ditemukan pada kelompok umur $3,0-5,9$. Perbedaan proporsi terduga pada berbagai postur tubuh di tiap kelompok umur hanya berbeda secara nyata di kelompok umur 1,0-2,9 (Chi-Square= 6,910; $d f=2 ; p=0,032$ ).

\section{BAHASAN}

Perkembangan keterampilan berbahasa dan kemandirian (personal social) tampak menyimpang pada anak berusia balita di Indonesia. Hal ini perlu eksplorasi lebih dalam. Di Indonesia, data efek pengasuhan psikologik pada perkembangan anak sangat sedikit dilaporkan. Anak berusia balita sering dianggap sebagai "boneka mainan" yang hanya perlu dihias, tetapi lupa akan haknya untuk memperoleh pengajaran bahasa (berbicara) dan mempersiapkan diri untuk mandiri. Anak sering diajak dengan bahasa bayi (baby talk) dan selalu perlu ditolong, akibatnya anak tidak belajar lafal yang benar dan tidak mandiri.

Secara umum perkembangan mental anak tidak berkaitan dengan postur tubuh anak. Namun demikian, berkaitan dengan aspek perkembangan kemampuan motorik dan kemandirian. Anak mempunyai postur tubuh normal cenderung lebih aktif (Pearson, $p=0,002)$ dan percaya diri (Pearson, $p=0,004$ ). Tampaknya informasi ini dapat mendukung efek pengasuhan psikologi pada perkembangan anak. Penelitian ini sejalan dengan hasil analisis dari review penelitian eksperimen dan kohor yang dilakukan Szajewska, et al dan Sachdev et al.

Tabel 3

Proporsi Perkembangan Mental ${ }^{*}$ menurut Kelompok Umur dan Postur Tubuh ${ }^{* *}$

\begin{tabular}{|c|c|c|c|c|}
\hline \multirow{2}{*}{ Kelompok Umur } & \multirow{2}{*}{ Postur Tubuh ${ }^{\star \star}$ ) } & \multicolumn{2}{|c|}{ Perkembangan Mental } & \multirow{2}{*}{ Total } \\
\hline & & Normal & Terduga & \\
\hline \multirow{4}{*}{$0,50-0,99$} & Sangat pendek & 40,0 & 60,0 & 100,0 \\
\hline & Pendek & 41,7 & 58,3 & 100,0 \\
\hline & Normal & 56,6 & 43,4 & 100,0 \\
\hline & Total & 54,2 & 45,8 & 100,0 \\
\hline \multirow[t]{4}{*}{$\overline{1,00-2,99}$} & Sangat pendek & 69,8 & 30,2 & 100,0 \\
\hline & Pendek & 82,2 & 17,8 & 100,0 \\
\hline & Normal & 84,5 & 15,5 & 100,0 \\
\hline & Total & 82,5 & 17,5 & 100,0 \\
\hline \multirow[t]{4}{*}{$3,00-5,99$} & Sangat pendek & 87,5 & 12,5 & 100,0 \\
\hline & Pendek & 79,5 & 20,5 & 100,0 \\
\hline & Normal & 81,2 & 18,8 & 100,0 \\
\hline & Total & 81,2 & 18,8 & 100,0 \\
\hline
\end{tabular}

*) Menurut empat aspek Denver II (all four); ${ }^{* *}$ ) Skor Z Tinggi Badan menurut Umur baku WHO 
Szajewska et al. (2010) melakukan review penelitian eksperimen dengan rancangan randomized controlled trials (RCT) tentang efek suplementasi zat gizi besi pada bayi dan anak (0-9 tahun) terhadap perkembangan mental dan psikomotor ${ }^{39}$ Penelitian tersebut dilaksanakan di Kanada, United Kingdom, Turki dan Indonesia. Hasilnya menunjukkan bahwa perkembangan psikomotor dipengaruhi oleh status anemia pada bayi dan anak tetapi perkembangan mental tidak terpengaruh. Lima tahun sebelumnya Sachdev et al. (2006) melakukan review penelitian RCT dan kohor tentang pengaruh suplementasi zat gizi besi terhadap pertumbuhan fisik. ${ }^{40}$ Hasil menunjukkan bahwa suplementasi zat gizi besi tidak berpengaruh terhadap pertumbuhan fisik termasuk postur tubuh.

Perlu diingatkan bahwa hasil pengukuran psikologik dengan metode DDST merupakan penapisan penyimpangan perkembangan. Keterlambatan perkembangan masih perlu dikonfirmasi lebih lanjut. Bayi masih tumbuh dengan cepat dan secara proses alami akan mengejar ketertinggalan. Oleh karena itu, informasi keterlambatan perkembangan pada bayi dalam artikel ini bukan hal yang definitif terlambat.

Artikel ini terbatas untuk memberikan informasi hasil penelitian SEANUTS aspek perkembangan anak berusia balita di Indonesia. Analisis yang lebih mendalam perlu dilakukan untuk memperoleh gambaran yang lebih lengkap. Pada artikel lain dapat dipelajari status zat gizi besi (anemia), data biomedis lainnya, konsumsi makanan, aktivitas anak dan status gizi yang berdasarkan penelitian merupakan faktor risiko pada perkembangan mental.

\section{SIMPULAN DAN SARAN}

\section{Simpulan}

Hasil SEANUTS memberi potret perkembanganmental anak Indonesia yang berusia di bawah lima tahun. Keterampilan berbahasa dan kemandirian anak terdeteksi terlambat dari pola perkembangan normal.

\section{Saran}

Perlu penelitian lebih lanjut yang mempelajari efek pola pengasuhan anak terhadap perkembangan mental anak Indonesia.

\section{UCAPAN TERIMAKASIH}

Kami mengucapkan terimakasih kepada FrieslandCampina sebagai penyandang dana penelitian ini, kepada direktur dan staf Frisian Flag Indonesia yang telah memfasilitasi dan menjadi penghubung peneliti dan penyandang dana. Terimakasih kepada teman-teman peneliti SEANUTS INDONESIA atas kerjasamanya melaksanakan penelitian ini.

\section{RUJUKAN}

1. Haddow JE, Palomaki GE, Allan WC, William JR, Knight GJ, Gagnon J, et al. Maternal Thyroid deficiency during pregnancy and subsequent neuropsychological development of the child. NEJM 1999; 341(8):549-555

2. Bambang-Hartono. The influence of iodine deficiency during pregnancy on neurodevelopment from birth to two years. Thesis. Amsterdam: University Amsterdam, 2001

3. Budiman B, Djokomoeljanto, Hadisaputro S dan Ekowarni E. Dampak defisiensi iodium maternal pada persistensi disfungsi neuropsikologis anak usia 12 tahun. Penelit Gizi Makan. 2012;35(1):23-33

4. Okano H, Sakaguchi M, Ohki K, Suzuki N, Sawamoto K. Regeneration of the central nervus system using endogenous repair mechanism. J Neurochem. 2007; 102: 1459-65

5. Auso E, Lavado-Autric R, Cueva E, Escobar del Rey F, Morreale de Escobar G, Berbel P. A moderate and transient deficiency of maternal thyroid function at the beginning of fetal neocortico genesis alters neuronal migration. Endocrinology.2004; 145:4037-4047

6. Schrimsaw NS. Malnutration, brain development, learning and behavior. Nutrition Reseach. 1998; 18 (20): 351-379

7. Pollit $E$, Saco-Pollit $C$, Jahari $A B$, Husaini MA and Huang J. Effects of an energy and micronutrient supplement on mental development and behavior under natural conditions in undernourished children in 
Indonesia. Euro J Clin Nutr. 2000; 54 (Suppl 2): S80-S90

8. Nunes ML. Malnutration and neuropsychomotor development. Jornal de Pediatria. 2001;77(3): 159-60

9. Guardiola A, Egewarth C, Rotta NT. Neuropsychomotor development in children and its relationship with nutritional status. J Pediatr. 2001;77(3)189-96

10. Mansur SS, Neto FR.Desvolvimento neuropsicomotor de lectentes des nutridos (neuropsychomotor development of malnourished babies). Revista Brasileira de Fisioterapia. 2006; 10(2): 185-191

11. Black MM, Baqui AH, Zaman K, Persson LA, El Arifeen S, Le $K$, et al.Iron and Zinc supplementation promote motor development and exploratory behavior among Bangladeshi infants. Am J Clin Nutr. 2004:80:903-10

12. Lind T, Lonnderthal B, Stendlund H. A Community base randomized controlled trial of iron and zinc supllementation in Indonesian infants: effects on growth and development. Am J Clin Nutr. 2004; 80:729-36

13. Dijkhuiszen MA and Wierenga FT. Vitamin A, Iron and Zinc Deficiency in Indonesia. Micronutrient Inter -action and Effects of supple -mentation. Thesis Wageningen: Wageningen University, 2001

14. Muskiet Muskiet FAJ, Fokkema MR, Schaafma A, Boersma ER, Crawford MA. Is docohexaenoic acid (DHA) essential? Lessons from DHA status regulation, our ancient diet, epidemiology and randomized controlled trials. J Nutr. 2004;134:183-6

15. McCann JC and Ames BN. An overview of evidence for casual relation between iron deficiency during development and deficits in cognitive or behavioral function. Am J Clin Nutr. 2007; 85:931-45

16. Felt BT, Beard JL, Schallert T, Shao J, Aldridge JW, Connor JR, Georgieff MK, Lozoff B. Persistent neurochemical and behavioral abnormalities in adulthood despite early iron supplementation for perinatal iron deficiency anemia in rat. Behav Brain Res. 2006; 171(2): 261-270

17. Hess SY, Zimmermann MB, Adou $P$, Torresani T, Hurrel RF. Treatment of iron deficiency in goitrous children improves the efficacy of iodized salt in Cote d'lvoire. Am J Clin Nutr. 2002;75:743-8

18. Hess SY. Interaction between iodine and iron deficiencies. Doctoral dissertation. Zurich: Swiss Federall institute of technology, 2003.

19. Bertrand PC, O'Kusky, Innis SM. Maternal dietary (n-3) fatty acid deficiency alters neurogenesisi in the embryonicrat brain. $\mathrm{J}$ Nutr. 2006; 1336:1570-5

20. Schmidt AT, Waldow KJ, Grove WM, Salinas JA, Georgieff MK. Dissociating long-term effects of fetal/ neonatal iron deficiency. Behav Neurosci. 2007;121(3): $475-82$

21. Lozoff B, Beard J, Connor J, Felt B, Georgieff, Schalert T. Long-lasting neural and behavioral effects of iron deficiency in infancy. Nutr Rev. 2006;64(5):S34-39

22. Innis SM. Dietary (n-3) fatty acid and brain development. J Nutr. 2007;137:855-9

23. Murray-Kolb LE, Beard JL. Iron treatment normalizes cognitive function in young women. Am J Clin Nutr. 2007;85:778-87

24. Zimmermannn MB, Connolly K, Bozo M, Bridson J, Rohner F, Grimci L. lodine supplementation improves cognition in iodine-deficient school children in Albania: a randomized, controlled double blind study. Am J Clin Nutr. 2006:83:108-14

25. Rivera JA, Hotz C, Gonzalez-Cossio T, Neufeld $L$ and Garcia-Guerra A. The effects of micronutrient deficiencies on child growth: A review of results from community-based supplementation trials. J Nutr. 2003;133:4010S-20S

26. Zimmermann MB, Wegmueller R, ZederC, ChaoukiN, BiebingerR, HurrellRF, at al.Triple fortification of salt with microcapsules of iodine, iron, andvitamin A1-3. Am J Clin Nutr. 2004;80:1283-90.

27. Etcheverry $P$, Griffin IJ, and Abrams SA. Micronutrient deficiencies: New Solution to a seemly irresolvable problem. Havard Health Policy Review. 2005;6(1):77-86.

28. Zimmermann MB. lodine deficiency in pregnancy and the effects of maternal iodine supplementation on the offspring: a review Am J Clin Nutr 2009;89 (suppl):668S-72S.

29. Beard J. Recent evidence from human and animal studies regarding iron status and 
infat development. J Nutr. 2007;137: 530S$542 S$

30. lanotti LL, TielschJM, Black MM, Black RE. Iron supplementation in early childhood: health benefits and risks. Am J Clin Nutr. 2006;84: $1261-76$

31. Gratham McGregor-S.Ani C. A review studies on the effects iron deficiency on cognitive develop ment in Children. J Nutr. 2001;131 (2S-2):649S-666S

32. Delange $F$. The role iodine in the brain development. Thyroid. 2000; 10(1):75-9).

33. Hawkes WC, Keim NL. Dietary Selenium intakes modulates thyroid hormone and energy metabolism in men. $\mathrm{J}$ Nutr. 2003; 133:3443-8

34. Hotz CS,Fitzpatrick DW, Trick KD, L'Abbe MR. Dietary lodine and Selenium Interact to effect thyroid hormone metabolism of rats. J Nutr. 1997;127:1214-8

35. Aihara K, Nishi $Y$, Hatano S, Kihara M, Yoshimitsu K, Takeichi N, Ito T, Ezaki $\mathrm{H}$, Usui T. Zinc, copper, manganese, and selenium metabolism in thyroid disease. Am J Clin Nutr. 1984;40:26-35

36. Frankenburg WK, Fandal AW, William Sciarillo W, and Burgess D.The newly abbreviated and revised Denver
Developmental Screening Test. The Journal of Pediatrics. 1981;99(6):995-999

37. Frankenburg WKand Dodds JB. The Denver Developmental Screening Test. The Journal of Pediatrics. 1967;71(2):215222

38. Sandjaja, Budiman-Basuki, HarahapHeryudarini, Soekatri-Moesijanti, ErnawatiFitrah, Widodo- Yekti E, et al. Desain Penelitian South-East Asia Nutrition Survey (SEANUTS) di Indonesia dan Jumlah Sampel Parameter Anak dan Rumahtangga. Gizi Indonesia. 2013;36 (2):75-89.

39. Szajewska $H$, Ruszczynski $M$ and Chmielewska A. Effects of Iron Supplementation in non anemic pregnant women, infants and young children on the mental performance and psychomotor development of children: a Systematic review of randomized controlled trials. Am J Clin Nutr. 2010;91:1684-90.

40. Sachdev HPS, Gera T and Nestel P. Effect of iron supplementation on physical growth in children: systematic review of randomized controlled trials. Public Health Nutrition. 2006; 9(7): 904-920 